\title{
Introduction to Workshop: Breeding, Growing, and Marketing of Repeat-fruiting Small Fruit Cultivars for an Extended Season
}

\author{
Justine E. Vanden Heuvel \\ University of Massachusetts Amherst, Cranberry Experiment Station, 1 State Bog Rd., \\ P.O. Box 569, E. Wareham, MA 02538 \\ Kimberly Lewers \\ USDA/ARS Fruit Laboratory, BARC-West, 10300 Baltimore Avenue, Beltsville, MD 20705 \\ Additional index words. primocane, raspberry, blackberry, strawberry
}

\begin{abstract}
Consumers, grocers, and distributors all want a year-round supply of fresh, highquality berries. Repeat-fruiting cultivars are being developed as a tool to meet that demand by extending the growing season for small fruit crops. To develop markets, cultivars, and production practices for repeatfruiting cultivars, research and extension professionals from many disciplines must communicate and collaborate.
\end{abstract}

The objective of our workshop was to explore approaches for marketing and breeding repeat-fruiting species in both basic and applied terms as well as development of production practices. What marketing opportunities are available for small fruit crops outside of the standard growing season? What genes and/or traits lead to repeat-fruiting? What progress is being made toward development of new repeat-fruiting cultivars? How does production of repeat-fruiting cultivars differ from standard production practices? Are there specific production challenges that need to be addressed in future breeding programs?

The articles published here provide information on breeding, producing, and marketing repeat-fruiting small fruit crops using day-neutral strawberry, primocane-fruiting blackberry, and primocane-fruiting raspberry as examples. 